between psychic processes and intra-orjanic and (I suppose) more especially, central nervous processes. With respect to the term "psycho-physiological," used by Dr. Hill in his syllabus, it may at least be said that it avoids the ambiguity of "psychophysics," as coined and defined by Fechner, while it is the direct descendant of the term "mental physiology," which is well fixed in British scientific literature.

I have only to repeat that Dr. Titchener's attempt to distinguish between the domains of physiological psychology and psychophysics seems to me far from adequate. It has about it, to my irreverent eyes, something of Wundt's own oracular obscurity.

In calling attention to reaction-time experiments, I did not refer to simfle reaction-times. I thought the various lines of experiment in which the processes of hesitation and selection, and so forth, are elucidated by measuring the intervals between sensory stimulus and muscular reaction might be brought under the head of reaction-time experiments. But not being in the privileged circle of working "psycho-physicists," I daresay I erred bere too.

This little discussion will not be in vain if it wake up Dr. Titchener, or some other working psycho-physicist, to the obscurities that hang over their new field of research for the outside student. It seems to me that we want careful definitions of the respective scopes of the several departments of research which are either psychological or which bear directly on psychology, more especially experimental psychology as a whole, psychophysics, and physiological psychology. Neither Wundt's nor Dr. Titchener's definitions satisfy some of us who, on this benighted island, provokingly placed between two luminous continents, are doing our best to catch some of the rays which they are shooting forth in such abundance.

THE. WRITER OF THE N OTE.

\section{Some Oriental Beliefs about Bees and Wasps.}

Sixce Baron Osten Sacken's letter appeared in Nature (vol. xlix. p. 199), I have been taking an occasional survey in my small library of Oriental literature, to inform him of passages referring to the Bugonia-superstition. So far as I could find, the people of the far East seem not to have possessed any belief about oxen-born bees; however, $a$ propos of this matter, I have come across several legends relating to some Hymenoptera, which I may group as Jollows :-

(1) Fossores Story. - Of all the insect stories of the far East, this may claim very high antiquity ; it was first celebrated, more than two thousand years ago, by a verse in the Confucianist "Book of Poems," and is, to this date, preserved by a well known metonymy "Ming-ling" (that is, the caterpillar), meaning the Foster-Child. This story, according to Yáng Hiung, a Chinese philosopher ( 53 B.C.-IS A.D.), was that "the Fossores, having no females, capture infant caterpillars from mulberry-trees, and address them a spell "Mimic me, mimic me," whereby they are turned into the young Fossores." Indeed, the Japanese name of the Fossores is Jiga (that is, "Mimic-me"). Against this Teól Hung.King, a Tauist sage (452-536 A.D.), has argued that these insects lave had offsprings of their own, but used to deposit the eggs on bodies of other insects to provide them with food in lucure.

(2) One.legged Wasp. - In Li Shi.Chin's work, cited above, we read:-"This production of Ling-nán, resembling a wasp, small and black, has one leg united with the root of a tree; it can move but cannot escape." Also a One-legged Ant is mentioned. I would suggest that these insects were infested by the forms of Cordyceps, as is instanced in the storits of $\mathrm{La}$ Guêpe Vegétále.

(3) Fungus.born Wasp. - Twan Ching-Shih's "Miscellanies," book xvii., contains the following note:- "A poisonous and noctilucous Fungus of Ling-nán is, after rain, metamorphosed into a large black wasp with serrate mandibles more than three. tenths of an inch long. At night it tries to enter the ears and nostrils of a man, and hurts him in his heart."

(4) Production of Anber from Bees. - In the same work, book xi.; is the following quotation from the "Record of Southern Savages":- "The Bees-with-Broken-Waists exist in the sands of Ning-chau, and come out when banks fall down ; the natives make amber by applying fire to them." Obviously this erroneous inference was drakin from the presence in amber of some hymenopterous remains.

(5) Diplera mistaken for Hymenopiera.-Sie Tsïi.Kang, NO. I 280 , VOL. 50] in his "Miscellanies of Five Phenomena" (Japanese edition, 166r, hook ix., p. 43), narrates thus :- "In Chang-sha I saw honey-bees all without sting;, so that, when trifled with upon the palms, they were quite harmless : having no difference from flies, that was strange!" No doubt he has seen some Eristalis, as is indicated by Baron Osten Sacken.

(6) Horse-hair Wasp.- Tazan Kan, a Japanese literatus (1748-1827), writes on this subject in his "Rambling Notes" (Tokio, I 890 , p. 22) :- "About 1817 a half-rotten trunk of Celtis sinensis gave birth to wasps, whose tails they could not withdraw from the tree, thus causing many to die. Having the tails cut with scissors the survivors gladly departed. One winter a man bought a heap of fuel comprising a half-rotten oak abounding with the similar wasps, several of which were strung on a horse-hair in the same manner as a rosary, there being altogether several dozens of such hairs. The author's informant took home a hair passing through three or four wasps, and folded it in paper; afterwards the hair became divided, and the insects bit through the paper : the informant's suggestion was- probably these wasps had been transformed from horse-hairs tangled round the rotten wood." ". Several times I have seen in Japan this so-called "Babi-bo" (the Horse-hair Wasp), still an object of popular amazement : it is nothing but an ichneumon-fy, Bracon fenetrator, whose ovipositor of unusual length has been the principal cause of such a superstition.

15, Blithfield Street, Kensington, W., April zo.

Kumagusu minakata.

P.S. - In my letter on the "Constellations of the Far East" (Nature, vol, xlviii, p. 542), I gave from Twan Ching.Shih's "Miscellanies" portions of the list of the objects of Indian fancy as to the resemblances of the constellations. Last March, my reverend friend, Atchârya Dharmanâga, then in Paris, kindly sent me an extract from Roshin Sennin's Lecture on the Constellations, recorded in Mahâsannipâta Sútra. After comparison, I find that both. quite agree except for a few variations, so that that Chinese author of "Miscellanies" seems to me to have extracted his list from the above-mentioned Indian authority.

K. M.

\section{The Mass of the Earth.}

I HAVE no intention of reopening a discussion on the advisability and necessity of carefully separating in our minds those two notions, the iveight of a body and its mass, which to me (and to a great many others) are now so completely distinct. The subject has already been treated of in these pages. Hence, in reply to the letter signed " $K$." I shall be very brief. The mtass of a body is simply the quantity of matter which it contains; its aveight is the force with which the earth pulls the body towards the centre of the earth; this force varies slightly at different points on the earth's surface, varies very much both when the body is removed outwards from the earth or inwards towards its centre, and would be nothing at all at the centre; the weight would be practically nothing if the body were removed a few millions of miles away from the earth. But through all these changes, and through all mere changes of place, the mass of the body is perfectly unaltered. Weight is a mere contingent property of mass, logically and physically distinct from it; a more contingent property than shape; for, while a body must have some shape, it need have no weight. The terms weight of the earth, weight of Jupiler, woight of the sutr, $\& c .$, are absulutely ridiculous. The mass of the earth is acted upon by no force whatsoever except the attraction of the sun and the disturbing attractions of the moon and the planets. The earth attracts itself with no force; it has no weight. So much for positive statement.

The notion that the earth has weight-the inability or neglect to distinguish the necessary property of constant mass from the contingent property of ziteight-has given rise to many absurdities. "If everything on the earth has weight, the whole earth has weight," is a fallacy of composition worthy of a mediaval dialectician. That the earth is a very heavy body (with, of course, an inveterate tendency to fall "down"), has supplied us with the assumption that it is supported on the back of an elephant, these two exceedingly heavy bodies being together supported on the back of a tortoise, and so on. To compare the avight of Jupiter with that of the sun, "imagine a gigantic balance with equal arms and equal pans; let the sun be placed in one pan; then, in order to freserze the balance, viore than 1000 Jupiters must be placed in; the other pan." 